\title{
Rhinoplasty. The Difficult Nasal Tip: Total Resection of the Alar Cartilages
}

\author{
Salvador Rodriguez-Camps
}

Received: 11 March 2008/Accepted: 11 July 2008/Published online: 16 September 2008

(C) The Author(s) 2008. This article is published with open access at Springerlink.com

\begin{abstract}
There are many ways to reconstruct and make nasal tips more attractive. Sometimes we cannot find the best way unless we at least remove all surplus from the tip. This may occur in primary or secondary rhinoplasty. In principle, anything is possible when relocating and reconstructing. However, sometimes we face reality when we uncover the tip: broken or bulging cartilages that are difficult to put right. For this reason, in 1987 we thought of totally resectioning the alar cartilages in a case of secondary rhinoplasty with an unsightly appearance. After a year the result was seen to be correct from an aesthetic and a functional perspective and is still so today. Aesthetically, it kept its shape and did not collapse with nasal respiratory failure. We covered the end of the crus medialis with a small, temporary, one- to two-layered fascia patch. Except in exceptional cases, we now use this procedure: Total sectioning of the alar cartilages including the domes, or maintenance of them by preserving the fibroadipose tip tissue with a suture in the middle of the end of the crus medialis and by covering this with temporary fascia, which usually has two layers depending on the thickness of the skin of the tip. This procedure is indicated mainly in secondary rhinoplasty when the cartilages of the tip are completely destroyed, and in primary rhinoplasty when the tip is excessively wide and bulbous. Our philosophy is, therefore, elegance and beauty of the nasal tip with a solid and equilateral base without prejudices.
\end{abstract}

S. Rodriguez-Camps ( $)$

Unidad de Cirugía Plástica y Estética, Hospital Universitario

"Casa de Salud", Manuel Candela, 41, 46021 Valencia, Spain

e-mail: cirugia-plastica@ rodriguez-camps.com
Keywords Rhinoplasty · Nasal tip · Alar cartilage · Nose reconstruction

\section{Methods}

When the size of the nostrils and the length of the columella are in proportion with the nasal base, we can directly proceed to the total sectioning of the alar cartilages, including the domes, with the help of certain technical recourses. Then we suture the distal ends of the crus medialis in the middle, and we cover them with a temporal two-layered fascia patch, or with a one-layered patch if required. Should the columella be excessively long and the nostrils be too large, we can proceed to resection a portion of the crus medialis and/or the alar wings to provide stability to the tip. If this is not done, the nose will collapse while inhaling and it will not look aesthetically correct. Indeed, we need a series of technical resources so that the resulting nasal base is equilateral [1] and solid. The resources that can help us are sectioning of the feet of the crus medialis, use of the converse stitch, narrowing nostrils, resectioning alar wedges, resectioning soft triangles, and maintaining the nasal tamponade for 3-4 days, the plaster splint for 7 days, and the plaster splint with steriStrip for an another 7 days. Probably after several months, the temporary fascia covering will produce a fibrous body that provides stability to the tip-columella-alar wings unit, and it will remain functionally firm [2-24].

\section{Results}

We have been performing this procedure since 1987 when we saw that the other tip-modeling methods did not 
produce the best results. At times, tip reconstructions with cartilages from the concha of auricle were no better than a total sectioning of the alar cartilages plus temporary fascia. Nonetheless, we are dealing with a procedure that is aimed at certain cases where the tip is extremely hard to correct [25-27]. If the correct proportion between the width and the length of the nasal base is maintained, then the tip is stable, aesthetically correct, and there will not be any failures of the nasal respiratory function (Figs. 1-14).
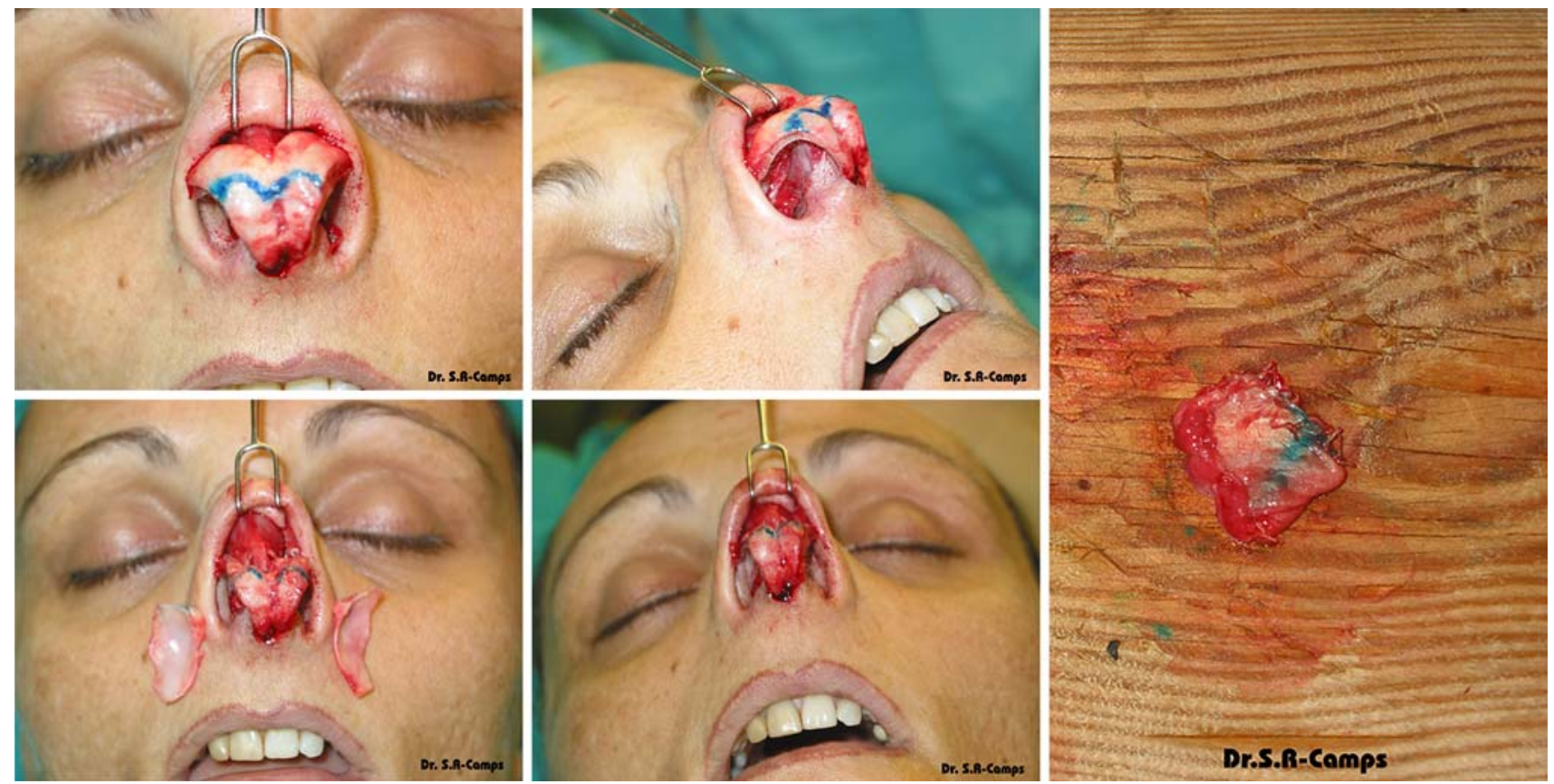

Fig. 1 Open rhinoplasty showing the cartilaginous structure of the nasal tip; resection and the temporal fascia patch
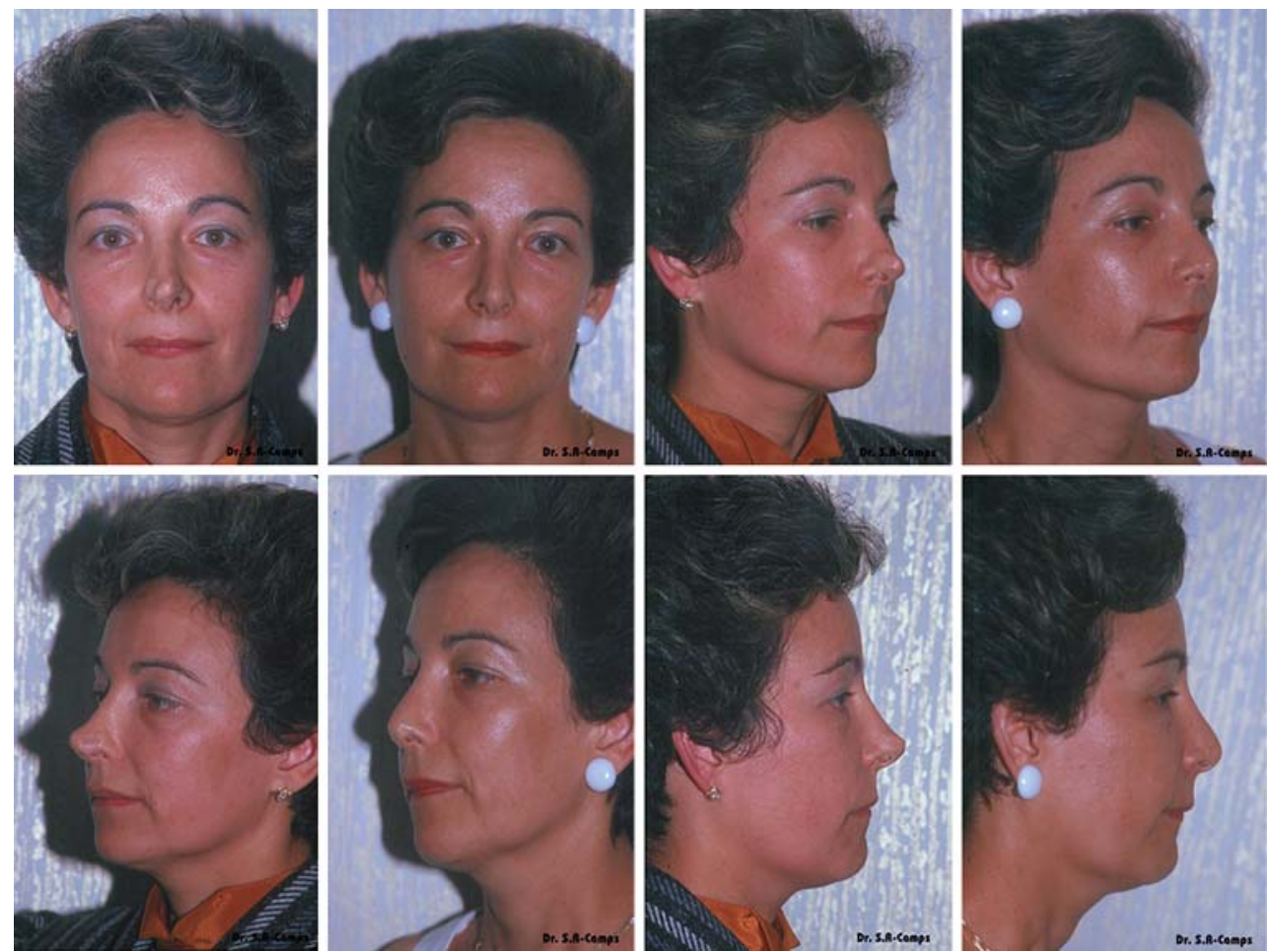

Fig. 2 My first case of total resection of the alar cartilages in a secondary rhinoplasty done in 1987. Preoperative views and 1 year later 


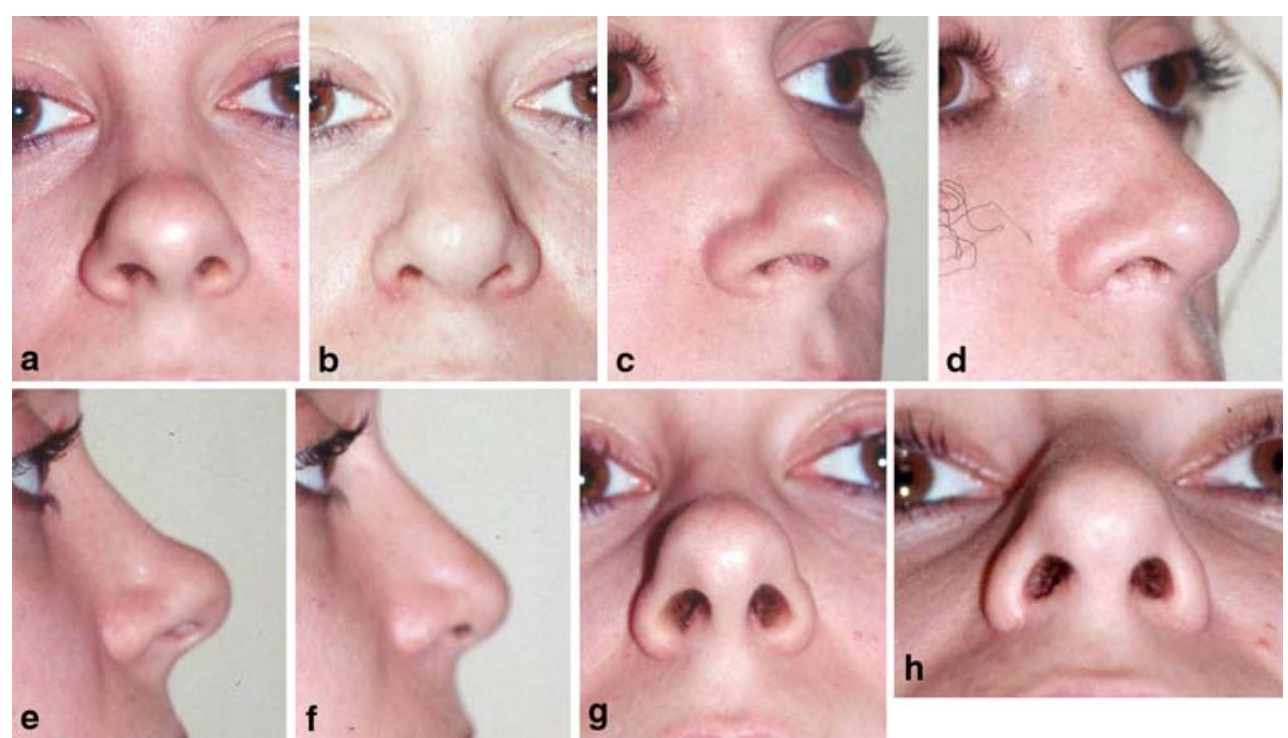

Fig. 3 Primary rhinoplasty for the "clown tip" which included total resection of the alar cartilages including the domes. Preoperative views and 1 year later

Fig. 4 Secondary rhinoplasty which included total resection of the alar cartilages including the domes: caudal septoplasty. Preoperative views and 1 year later
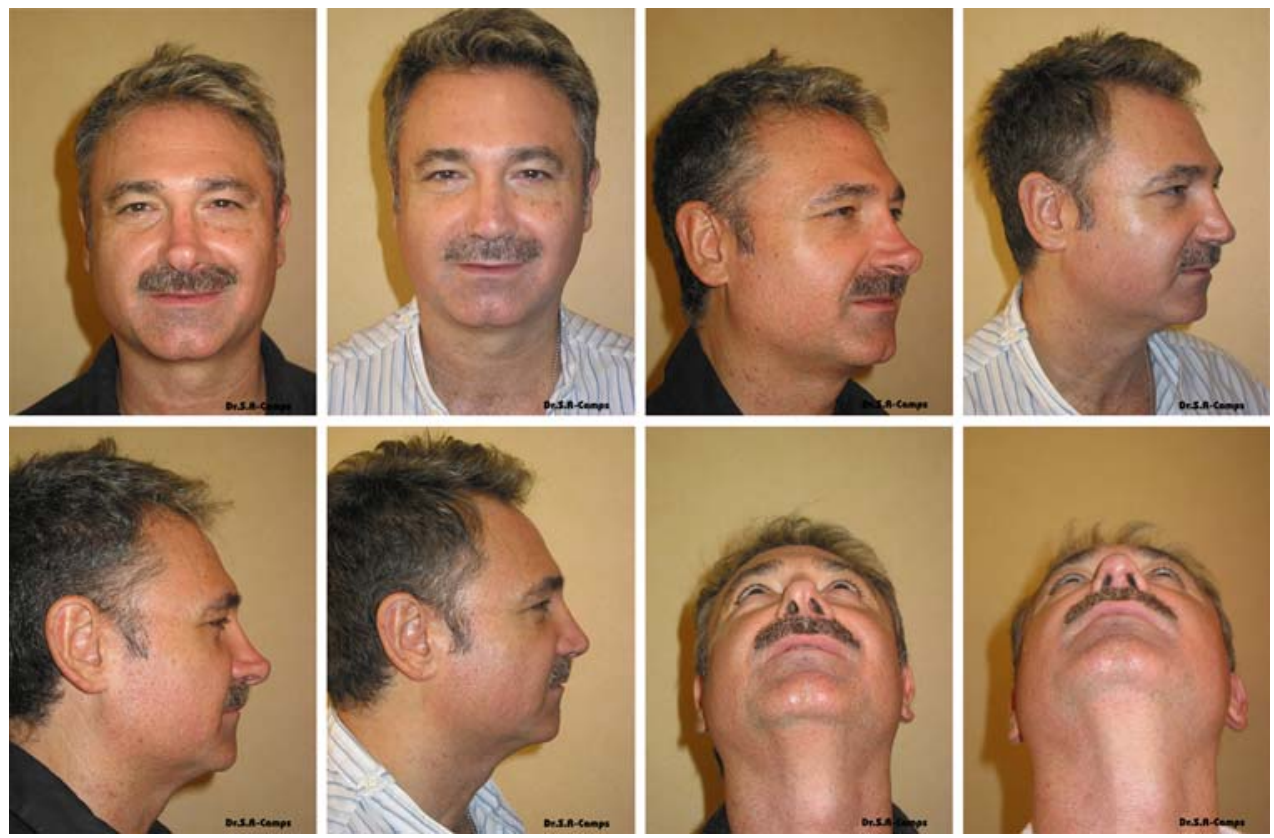

\section{Conclusions}

This procedure may appear to be harsh and frivolous. However, we have not seen any aesthetic or functional sequelae in 20 years and 200 operations in which this technique was used. Moreover, we never reconstruct the alar cartilages in postsection nasal reconstruction through cancer
[28], and we have never had problems related to the collapse of flaps. It is very important to ensure that the height and the width of the nasal base are in proportion (equilateral nasal base) to avoid a collapse with nasal respiratory failure. Furthermore, it is necessary that any respiratory obstacle such as nasal septum deviation, particularly hypertrophy of the turbinates, be resolved in the same surgical procedure. 

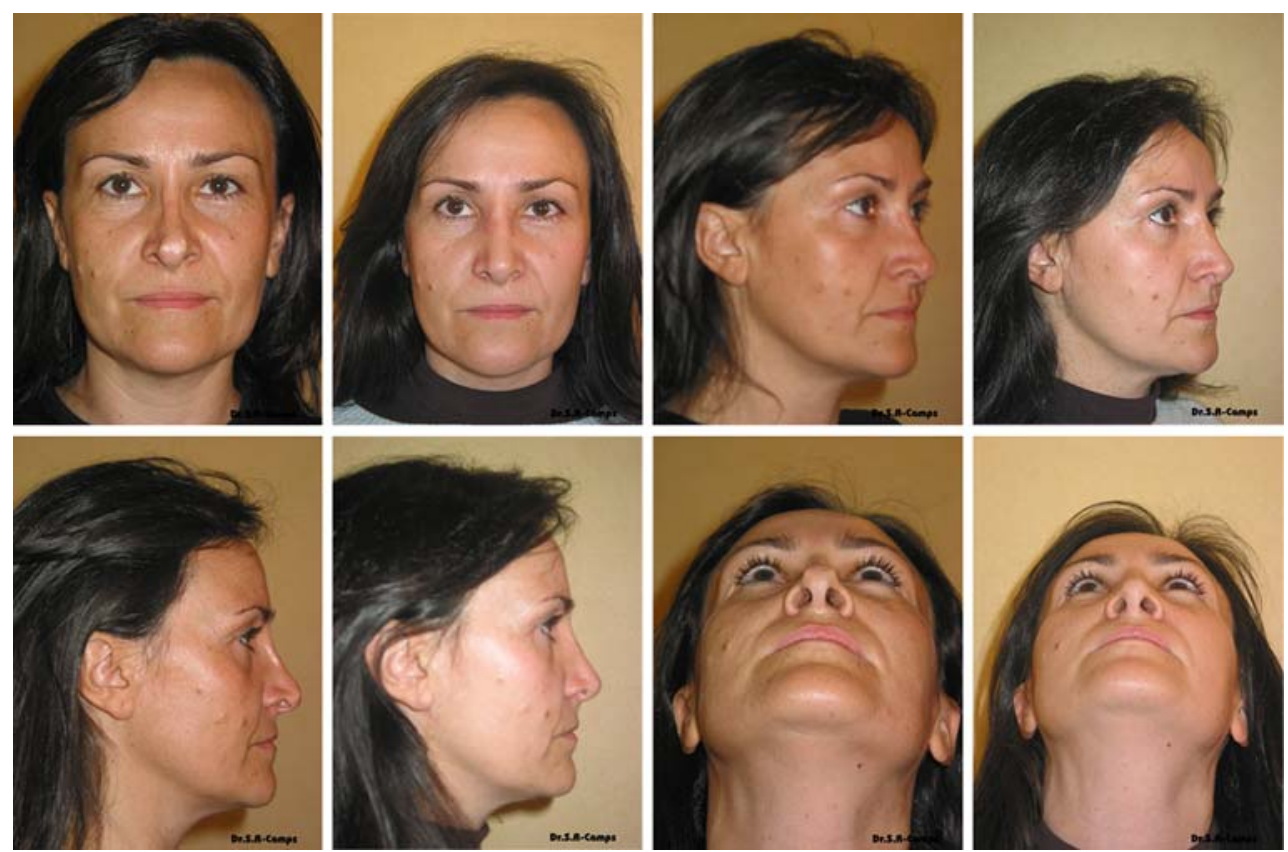

Fig. 5 Secondary rhinoplasty which included total resection of the alar cartilages including the domes: temporal fascia patches in the tip and laterally. Preoperative views and 1 year later

Fig. 6 Primary rhinoplasty for broad and bulbous nasal tip which included total resection of the alar cartilages preserving the domes. Preoperative views and 1 year later
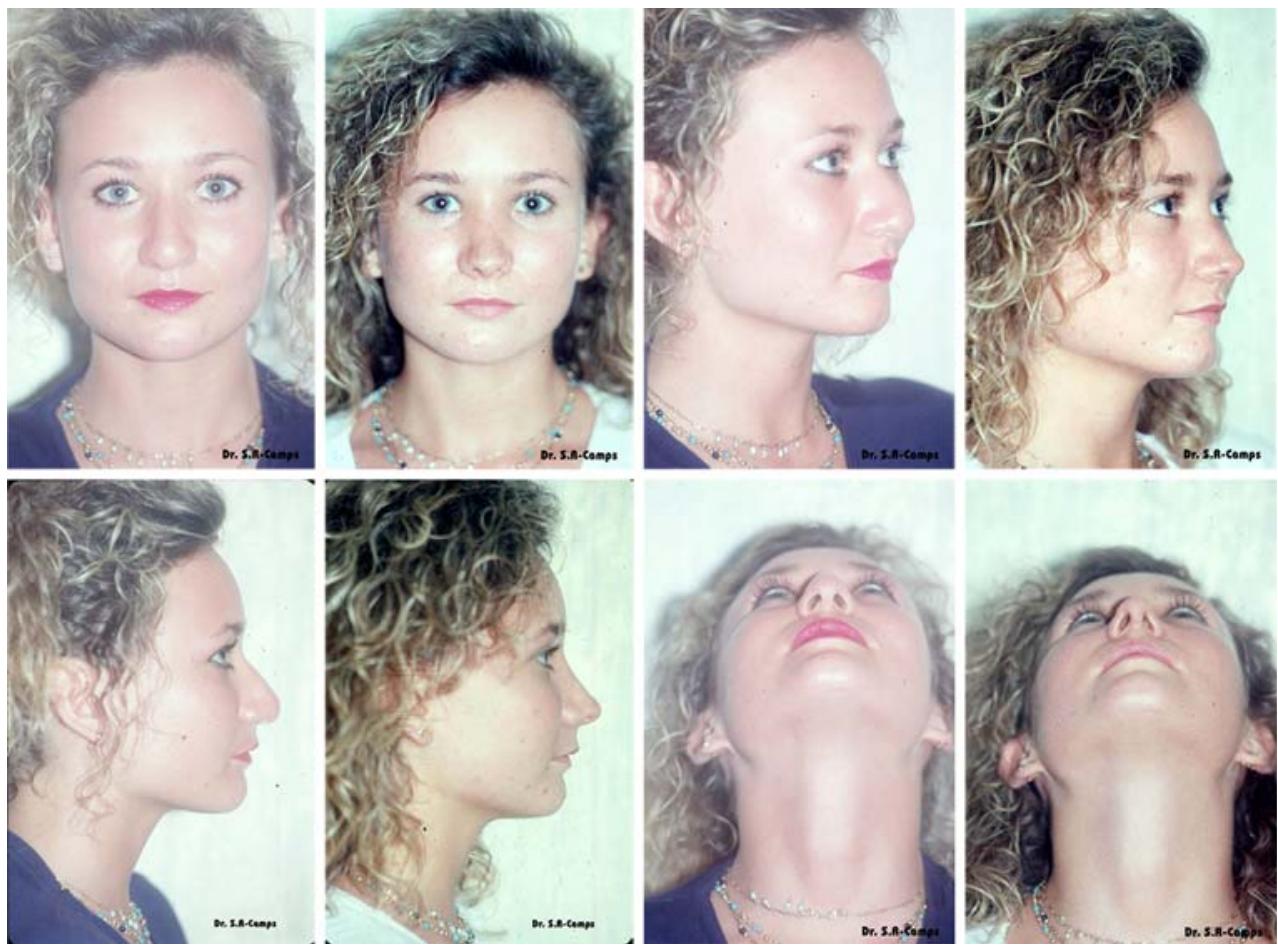
Fig. 7 Secondary rhinoplasty for "Pinocchio tip" which included total resection of the alar cartilages including the domes and a cephalic portion of the crus medialis. Preoperative views and 1 year later
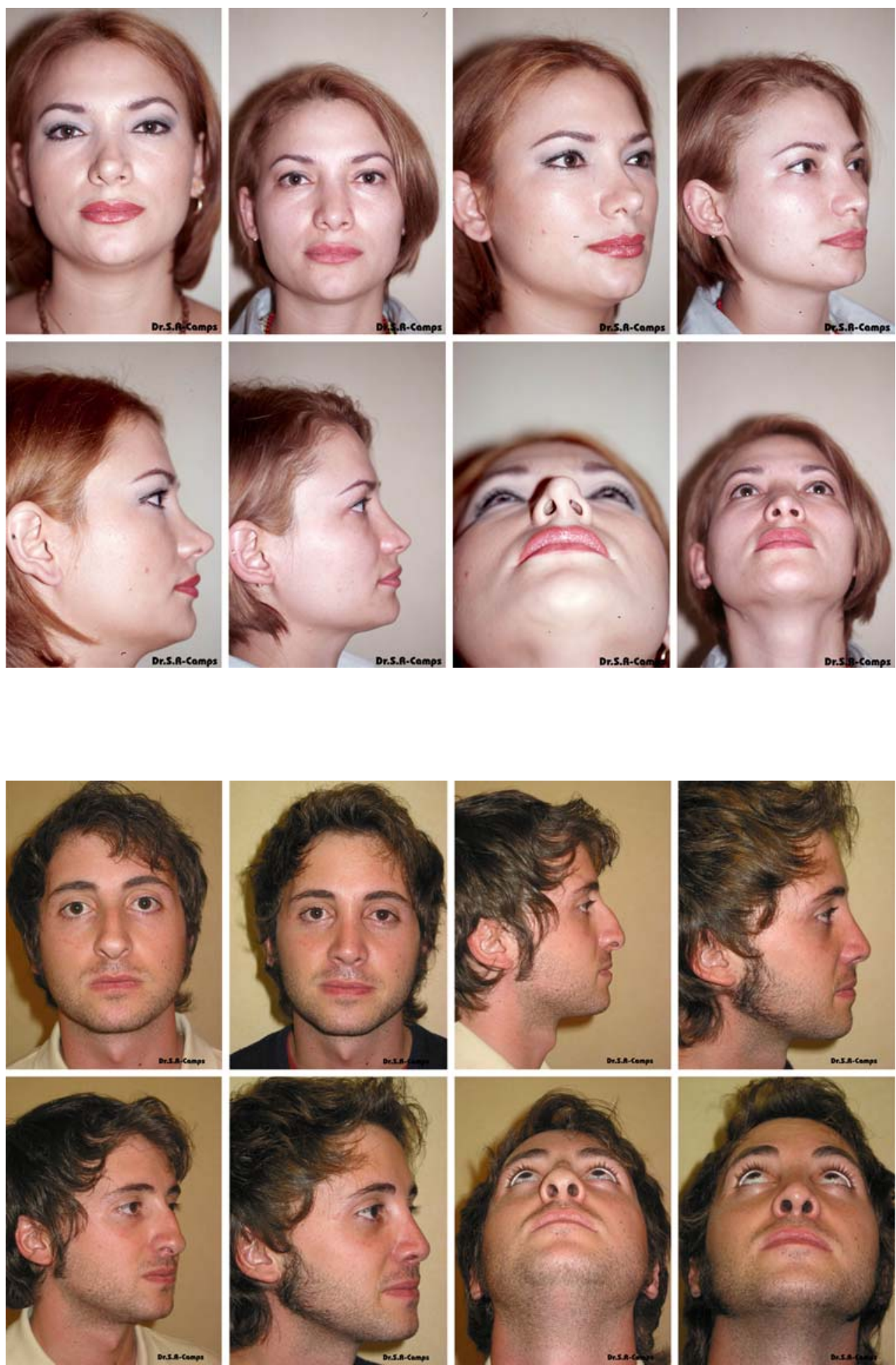
Fig. 9 Primary rhinoplasty for broad and bulbous nasal tip which included total resection of the alar cartilages including the domes. Preoperative views and 1 year later
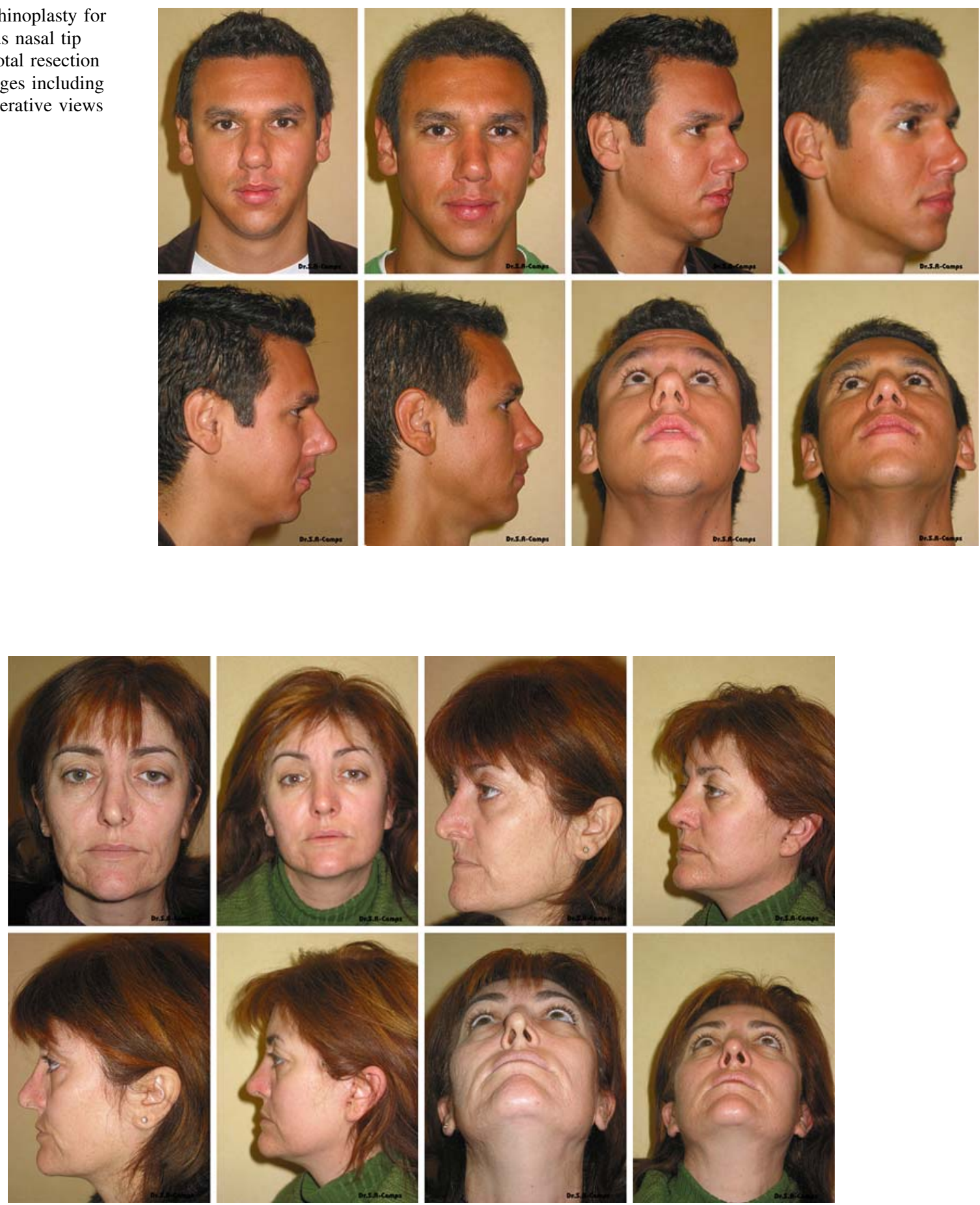

Fig. 10 Secondary rhinoplasty with total resection of the alar cartilages including the domes. Preoperative views and 1 year later 
Fig. 11 Primary rhinoplasty for extremely broad and flat nasal tip which included total resection of the alar cartilages including the domes.

Preoperative views and 1 year later
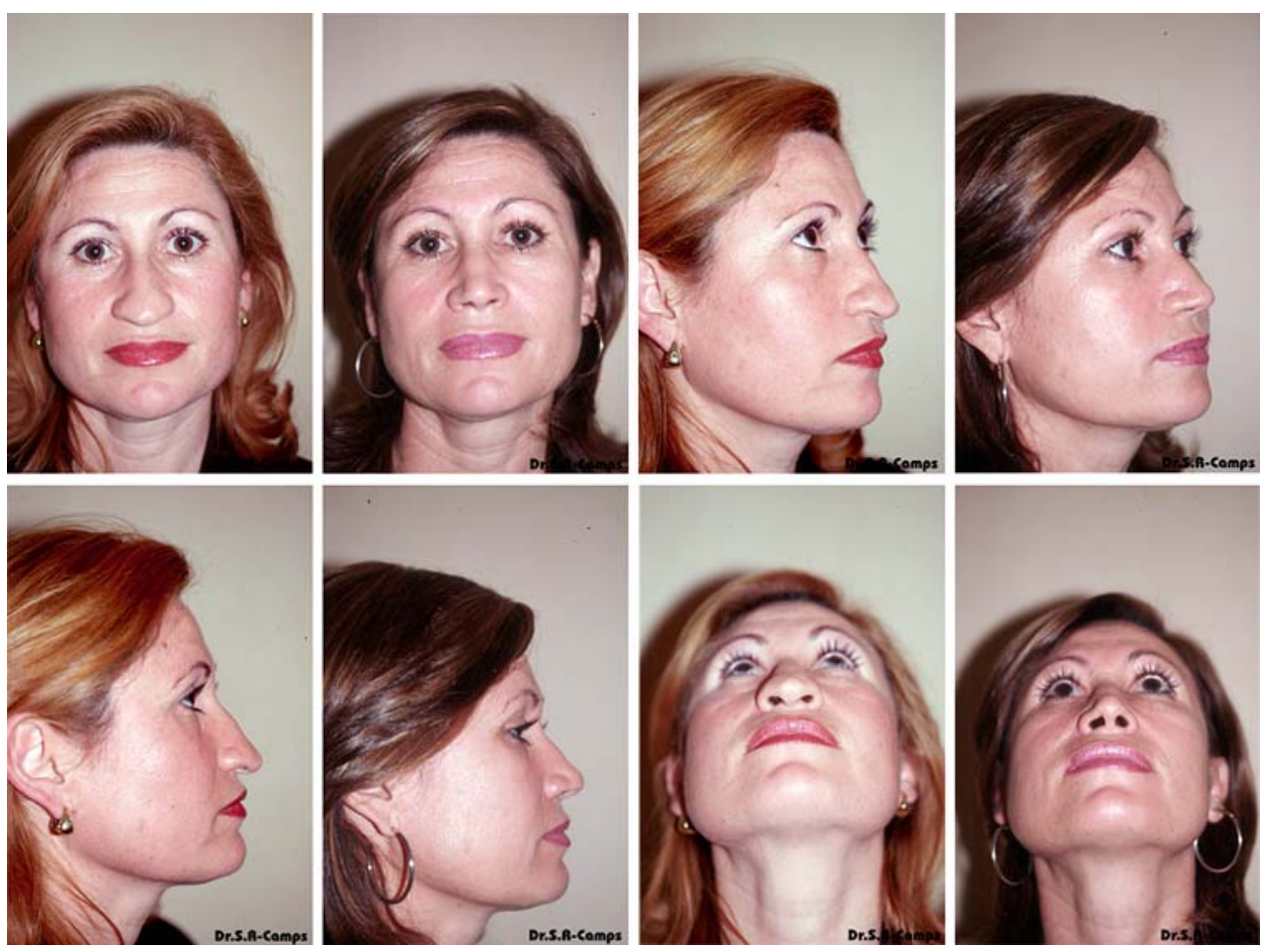

Fig. 12 Primary rhinoplasty for broad and bulbous nasal tip which included total resection of the alar cartilages including the domes. Preoperative views and 1 year later
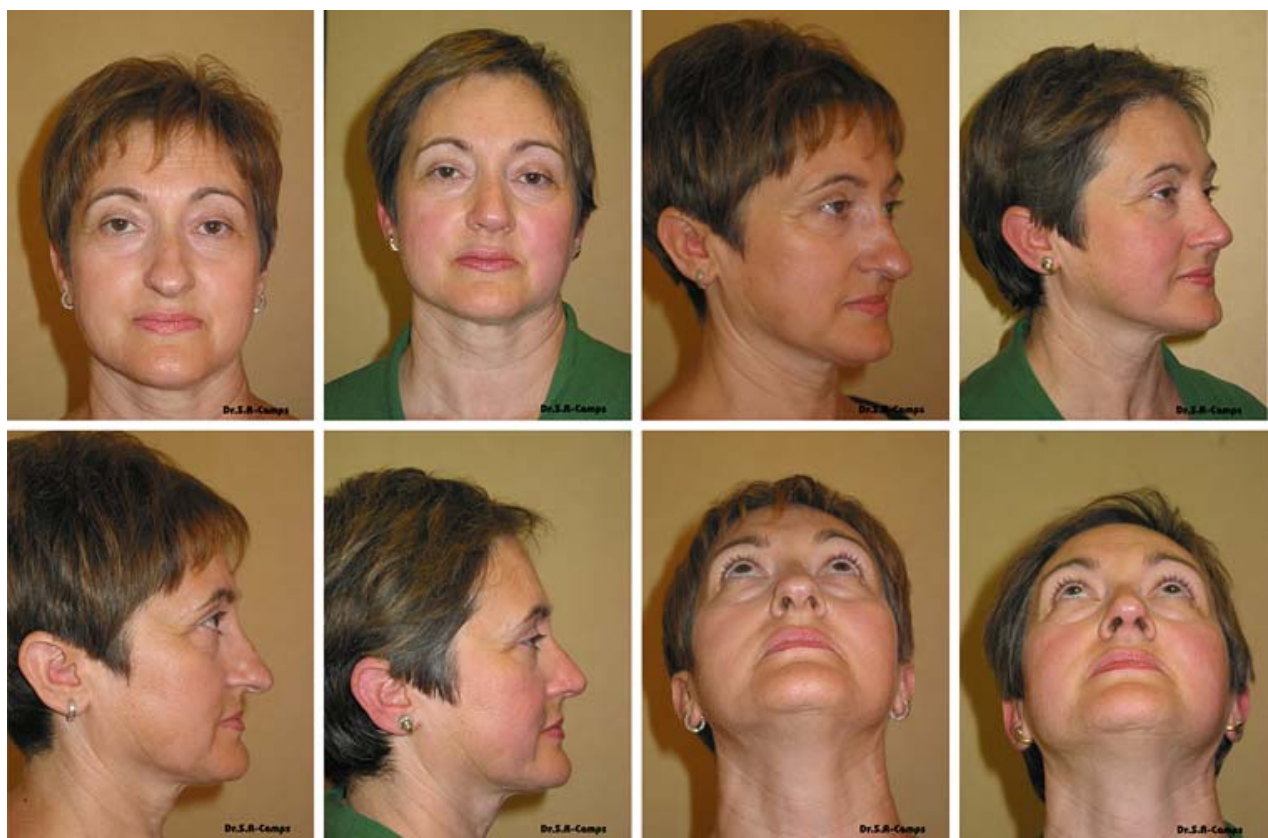
Fig. 13 Secondary rhinoplasty with total resection of the alar cartilages. Preoperative views and 1 year later

Fig. 14 Primary rhinoplasty with total resection of the alar cartilages: caudal septoplasty. Preoperative views and 1 year later
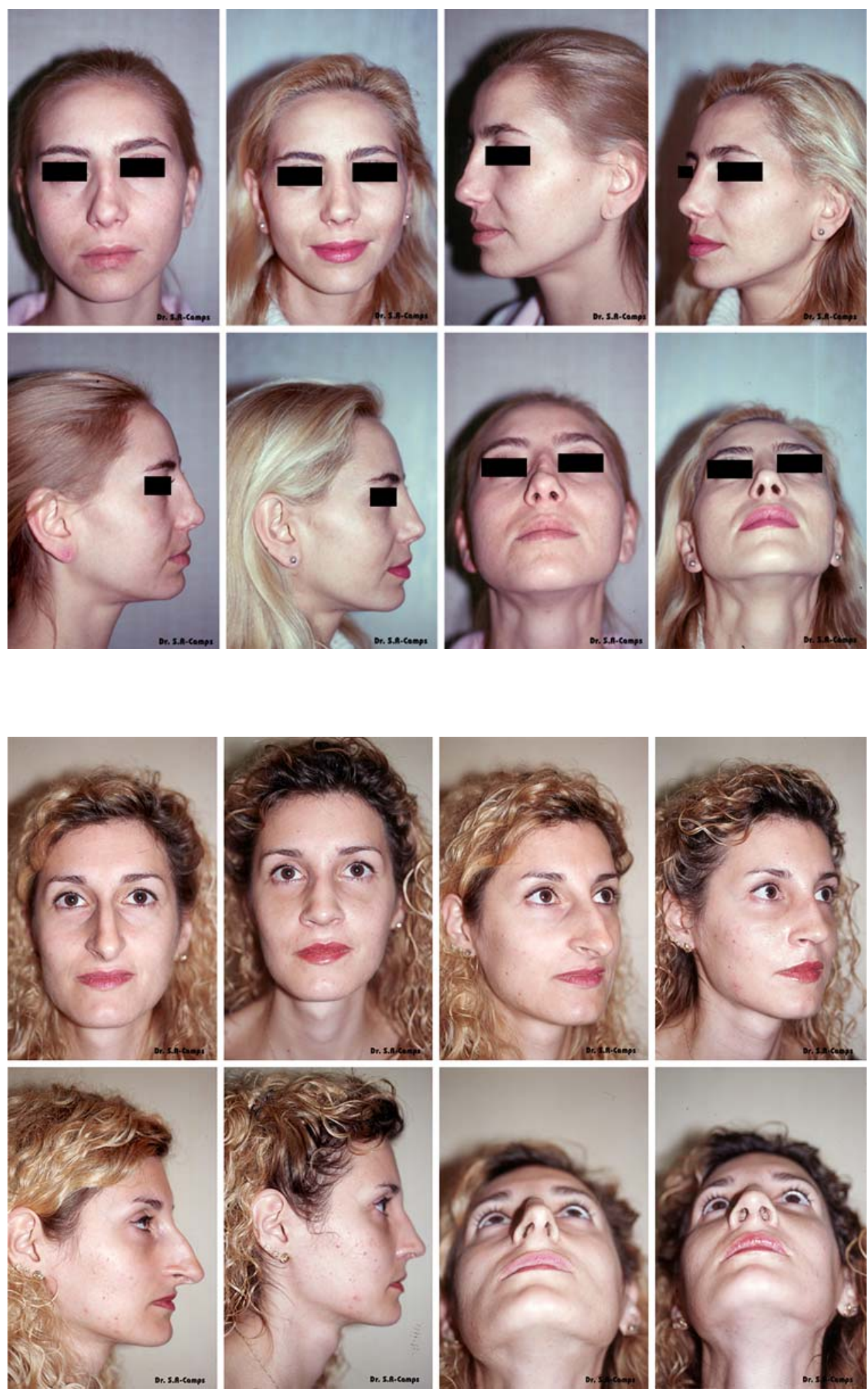
Open Access This article is distributed under the terms of the Creative Commons Attribution Noncommercial License which permits any noncommercial use, distribution, and reproduction in any medium, provided the original author(s) and source are credited.

\section{References}

1. Tardy ME Jr (1990) Surgical anatomy of the nose, 1st edn. Raven Press, New York

2. Converse J (1977) Reconstructive plastic surgery, 2nd edn. W.B. Saunders, vol 2, chap 29, pp 1040-1281

3. Meyer R (1988) Secondary and functional rhinoplasty: the difficult nose, 1st edn. Grune \& Stratton, Orlando, FL

4. Rodriguez-Camps S (1989) Secondary rhinoplasty for leporine nose: open technique. Ponencia con vídeo. XX Reunión Nacional de la Sociedad Española de Cirugía Plástica, Reparadora y Estética (SECPRE), León, Spain, October 1989

5. Rodriguez-Camps S (1994) Reconstruction of the nose after micrographic Mohs surgery. Póster. Congreso Nacional de la Sociedad Española de Cirugía Plástica, Reparadora y Estética (SECPRE), Valladolid, Spain, June 1994

6. Rodriguez-Camps S (1995) Total reconstructive rhinoplasty with mediofrontal flap. Ponencia con vídeo. VIII Congreso de la Sociedad Española de Cirugía Plástica, Reparadora y Estética (SECPRE), Santiago de Compostela, Spain, June 1995

7. Rodriguez-Camps S (1995) Nasal reconstruction after Mohs micrography surgery. Cir Plast Iberolatinoam XXI(3):215-223

8. Rodriguez-Camps S (1995) Nose reconstruction with medial forehead flap after Mohs surgery. Int Video J Plast Aesthetic Surg 2(3) December

9. Rodriguez-Camps S (1996) Aesthetic rhinoplasty under local anaesthetic without sedation. Ponencia con vídeo. XXXI Congreso de la Sociedad Española de Cirugía Plástica, Reparadora y Estética (SECPRE), Madrid, Spain, September 1996

10. Rodriguez-Camps S (1997) Augmentative rhinoplasty with auricular cartilage. Ponencia. Congreso Nacional de la Sociedad Española de Cirugía Plástica, Reparadora y Estética (SECPRE), Barcelona, Spain, April 1997

11. Rodriguez-Camps S (1998) Basocellular epithelioma recidivation of the nasal tip. Sectioning. Reconstruction in two steps with frontal flap. Ponencia. Symposium de Cirugía Plástica Nasal, homenaje al Profesor Benito Vilar-Sancho. Hospital Ramón y Cajal, Madrid, Spain, February 1998

12. Rodriguez-Camps S (1998) Augmentative rhinoplasty with an auricular gibbus. Aesthetic Plast Surg 22:196-205

13. Rodriguez-Camps S (1999) Miscellaneous primary and secondary rhinoplasty. Ponencia. XXXIV Congreso de la Sociedad Española de Cirugía Plástica, Reparadora y Estética (SECPRE), Marbella, Spain, April 1999

14. Rodriguez-Camps S (2000) Rhinoplasty: primary, secondary and reconstructive. II Reunión de la Sociedad de Cirugía Plástica,
Recontructiva y Estética de la Comunidad Valenciana (SCPRECV), Alicante, Spain, February 2000

15. Rodriguez-Camps S (2001) Nasal reconstruction after epithelioma. Aesthetic Plastic Surg 25(4):273-277

16. Rodriguez-Camps S (2002) Aesthetic nasal reconstruction. In: Libro Ponencia Oficial del XXXVII Congreso Nacional de la Sociedad Española de Cirugía Plástica, Reparadora y Estética (SECPRE) "Rhinoplasty," Oviedo, Spain, June 2002, chap 11

17. Rodriguez-Camps S (2004) Rhinoplasty: the aesthetic tip-columella-lip unit. Ponencia. XV Congreso de la Federación Iberolatinoamericana de Cirugía Plástica (FILACP) y XXXIX Congreso Nacional de la Sociedad Española de Cirugía Plástica, Reparadora y Estética (SECPRE), Seville, Spain, May 2004

18. Rodriguez-Camps S (2004) Rhinoplasty: the nasal base. Ponencia. V Reunión de la Sociedad de Cirugía Plástica Reparadora y Estética de la Comunidad Valenciana (SCPRECV), Alicante, Spain, November 2004

19. Rodriguez-Camps S (2005) Nasal reconstruction. Ponencia. VI Reunión de la Sociedad de Cirugía Plástica, Reparadora y Estética de la Comunidad Valenciana (SCPRECV), Valencia, Spain, October 2005

20. Rodriguez-Camps S (2005) Closed rhinoplasty. Curso Docente de Cirugía Plástica, Reparadora y Estética, Facultad de Medicina de la Universidad de Barcelona, Conferencia, Barcelona, Spain, November 2005

21. Rodriguez-Camps S (2006) Secondary rhinoplasty: our procedures. Total section of the alar cartilages and domes, with temporary fascia closure on the tip. Ponencia. XLI Congreso de la Sociedad Española de Cirugía Plástica, Reparadora y Estética (SECPRE), Pamplona, Spain. May 2006

22. Rodriguez-Camps S (2006) Nasal Reconstruction. Ponencia. VII Reunión de la Sociedad de Cirugía, Plástica, Reparadora y Estética de la Comunidad Valenciana (SCPRECV), Alzira, Valencia, Spain, October 2006

23. Rodriguez-Camps S (2006) Reconstructive rhinoplasty. Curso Docente de Cirugía Plástica, Reparadora y Estética, Facultad de Medicina Universidad de Barcelona, Barcelona, Spain, November 2006

24. Rodriguez-Camps S (2008) Rhinoplasty. the difficult nasal tip: total resection of the alar cartilages. 19th Congress of the International Society of Aesthetic Plastic Surgery, (ISAPS), Melbourne, Australia, February 2008

25. Juri J, Juri C, Grilli D, Zeaiter MC, Belmont J (1986) Correction of the secondary nasal tip. Ann Plast Surg 16(4):322-332

26. Peck G (1984) Techniques in aesthetic rhinoplasty, 1st edn. Gower Medical Publishing, New York

27. Sheen J (1978) Aesthetic rhinoplasty, 2nd edn. C.V. Mosby, St. Louis, MO

28. Burget G, Menick F (1994) Aesthetic reconstruction of the nose, 1 st edn. C.V. Mosby, St. Louis, MO 